\title{
Beekeeping in Tanzania: why is beekeeping not commercially viable in Mvomero?
}

\author{
Nicholaus B. Tutuba (1), Wim Vanhaverbeke (2) \\ (I) School of Business, Mzumbe University. Tanzania \\ (2) Strategy \& Innovation Management, Hasselt University, Belgium
}

\begin{abstract}
Beekeeping is a long established economic activity in Tanzania. It contributes to the national economy by generating some US\$ I9 million per annum and employing more than two million people. Beekeeping produces food and medicines, makes a significant contribution to bio-diversity, and encourages agricultural production through pollination. Moreover, more than $50 \%$ of Tanzania is covered by forests suitable for beekeeping. This potential is not fully exploited, and the sector is non-commercial. This study analyses the causes of the inability of rural Tanzanian beekeepers to establish commercially viable businesses. Using the case study research design, this qualitative study was conducted in the Mvomero district. Triangulation sampling techniques were used to select different beekeeping actors. Data was collected through interviews, focus group discussions, and observation. The descriptive analysis and 'current tree reality' of thinking process techniques were used to identify constraints that limit beekeepers from commercialising the sector. The challenges that are repeatedly cited as the main hindrances to the growth and development of beekeeping include over-reliance on traditional hives and honey production methods, low volumes, poor quality honey, limited access to finance, and insufficient fodder. We conclude that insufficient beekeeping expertise (knowledge and skills) and management are the two critical underlying factors that have led to the current situation. Since this study was limited to answering the first question of the theory of constraints approach, a further study is suggested to answer the remaining two questions. Moreover, a study to assess obstacles that hinder the adoption of top bar hives in the area is vitally important.
\end{abstract}

Key words: beekeeping, commercial beekeeping, theory of constraints, beekeeping constraints, Tanzania

\section{Introduction}

Beekeeping is the practice of managing honeybees (MatchMaker Associates Limited [MMA], 20I2) for obtaining bee products. The products produced include honey, live bees, and beeswax - as well as propolis, bee venom, royal jelly, brood, bee-soup, and queen bees (Ministry of Natural Resources and Tourism [MNRT], I998; and MNRT, 200I; The Beekeeping Act, 2002). Similarly, bee-colonies, and bee-collected pollen can be harvested from the hive (Abdu, 20I2; Collison, 2004; Food and Agricultural Organization [FAO], 20I2; Kugonza, 2009; MMA, 20I2). Despite the high value of apiculture 
products in local, regional, and international markets (Belgium Technical Cooperation [BTC], 2013; International Trade Centre [ITC], 2015), and the recognised social and economic benefits of beekeeping, the sector in Tanzania remains non-professional and non-commercial. There is thus a need to study the factors and issues behind the lack of commercial success, in the present study we examine beekeeping in Mvomero. To understand the constraining factors for commercial beekeeping in Tanzania, the Theory of Constraints (Dettermer, 2000; Goldrattt and Cox, 2004) was used.

This study is organised into five sections: study concepts, literature review, approach and methodology, findings and discussion, and a conclusion. Firstly, the study concepts are presented to give a common understanding of beekeeping in general, commercial beekeeping, and beekeeping in Tanzania. Secondly, a literature review presents the theory of constraints and how it has been applied in the empirical analysis of beekeeping constraints in other studies. The third part contains the approach and methodology, and explains how the study was conducted. This section is followed by the findings and discussion. Given the nature of the study, it is important that every finding is discussed after its presentation. This gives an opportunity to focus on and explain one issue at a time. Finally, we conclude this study by summing up the potential constraints for beekeeping commercialisation in Tanzania, and areas for further studies are identified and presented.

\section{Study concepts}

\subsection{Beekeeping}

Beekeeping, also known as apiculture or meliponiculture, has been defined in various ways (Alfred and Roger, 2008; Cadwallader, 20II; Guyo et al., 20I5; MNRT, I998). But all definitions point to the art of managing honeybees sustainably for the purpose of tapping into the resource benefits. Beekeeping is more than collecting and retaining bees in a hive and apiary, or putting a hive in an apiary and waiting to benefit from the bee colony. Beekeeping involves effectively and sustainably managing the bee colony. This requires modern types of equipment and tools, applying appropriate beekeeping knowledge and skills, and accessing potential and profitable markets.

Beekeeping and honey-hunting have informally been practiced for many generations in Tanzania. The British colonial government formed a department responsible for beekeeping within the Ministry of Agriculture in 1949. In I998, a national beekeeping policy (NBP) was formulated. Responsibility for beekeeping was transferred to the Ministry of Natural Resources and Tourism (MNRT, I998), within the forests and beekeeping department. The implementation of the NBP was backed by the 2002 Beekeeping Act and a ten-year national beekeeping programme (MNRT, 200I). These efforts were intended to professionalise the sector so that it can sustainably contribute to socio-economic development and environmental conservation (Mpinga, 20r6). Another objective was to increase hive productivity and export earnings from honeybee products (MNRT, I998). Furthermore, several projects (BTC, 20I2; BTC, 2007) and programmes (MNRT, 200I) were implemented by development partners and the private sector (MMA, 20I2; MMA, 
2007). These initiatives were aimed at showing the social and economic potential of beekeeping, and converting it into a commercial sector.

Despite these efforts, the impact on the ground has been disappointing: rural beekeepers remain local and relatively poor. Quality and quantity produced per hive is still below average, and production of products other than honey and beeswax has not begun (MMA, 2007 MMA, 2012; Kuboja, 2015). Moreover, exports of honey and beeswax have been declining despite the rise in global demand and increase in investment (ITC, 20I5). This situation raises a number of questions. Why is the beekeeping sector in Tanzania performing below par? Why is the sector not commercially managed in light of the available opportunities for commercial beekeeping? What are the factors constraining its commercialisation? This study contributes to a theoretical understanding and application of the theory of constraints, and also builds on the body of literature on the factors constraining commercial beekeeping.

\subsection{Commercial beekeeping}

In developing areas, beekeeping is a traditional honey-hunting (Guyo et al., 2015) and rural-based activity. It is mostly practiced by local communities (Mpinga, 2016; MNRT, I998; Nyatsande et al. 2014) using local means - in which hive management is critical.

Unlike other rural economic activities, such as arable farming and animal husbandry, beekeeping is given very little attention. There have been no clear responsibilities concerning the development of the sector. For example, at the national level, the ministry of natural resources and tourism is responsible for policy and programmes. But at the operational level, district beekeeping officers (reporting to local government in the president's office) are responsible. Beekeeping is considered an agricultural, forestsupporting activity, and also a natural resource and tourism activity.

Moreover, the sector has limited extension services and relies on the use of local types of equipment and tools in harvesting, extraction, processing, and the packaging of hive products (MMA, 20I2; Mwakatobe, 2006; Nyatsande et al. 20I4). This has resulted in low productivity, low quality hive products, and unreliable markets. The sector has failed to tap into the potential social and economic benefits.

In contrast, beekeeping has been treated differently in developed areas. The sector has been changed by the use of top bar commercial hives, and modern beekeeping equipment and tools. Productivity has increased, and product quality improved. Most important, other hive products such as royal jelly, pollination services, bee collected pollen and bee venom have been harvested. These products command a higher price than honey and beeswax. Therefore, they provide more options for commercial production, and increase the income of the beekeeper.

Also, the inclusion of other potential actors in the beekeeping value chain is important. The beekeeping sector extends to other economic activities beyond the activities of beekeepers. For example, innovation in engineering can create extraction and packaging machines that reduce contamination. Universities can conduct research on more produc- 
tive bee species. Tailors can make more effective protective clothing. Therefore, inclusive beekeeping promotes sustainable beekeeping practices. It improves productivity, product quality, and access to potential and profitable markets. This is commercial beekeeping.

Commercial beekeeping is, therefore, the modern art and science of managing honeybees for the purpose of tapping their commercial potential. The management of honeybee colonies includes pest and predator control, apiary management, colony manipulation, bee forage, record keeping, and production, and product management. Modern beekeeping includes the use of commercial hives, appropriate beekeeping tools and equipment, suitable beekeeping technologies, and operating within a well-defined, or structured value chain. But the challenge is to explain why Tanzanian beekeepers have not managed to transform the sector? What are the issues hindering them from changing available opportunity into commercial beekeeping? This can be understood by reviewing commercial beekeeping in Tanzania.

\subsection{Commercial beekeeping in Tanzania}

Beekeeping is often promoted as a rural business. Unlike urban areas, rural areas are less polluted and hence provide the vegetation suitable for bees to make quality organic products. Beekeeping is also considered a rural activity because all members of the community can do it, and start-up costs are relatively low. Moreover, it integrates with other agricultural activities without competing for resources, and protects the environment (Bee for Development, 2006; Kagonza, 2009; Nyatsande et al., 20I4).

Tanzania is among the countries in the world with the highest potential for production of bee products (Mwakatobe, 2006; Pinda, 20I4; MNRT, I998). However, only around $7 \%$ of its beekeeping capacity is utilised, and about $3 \%$ of its honey and beeswax is exported (Pinda, 20I4; Mbeiyererwa, 20I4). These figures are all the more surprising when we consider that Tanzania is the second largest honey producer in Africa, after Ethiopia, and tenth in the world (Guyo, 2015; Nyatsande et al., 2014). There is clearly an opportunity for transforming the sector from a non-professional and local activity into a sustainable commercial investment.

'Tanzania has the potential of exporting more than 5,000 tons of honey and all of the beesffwax produced. The beekeeping sector is still a virgin industry for rewarding investment. More than $90 \%$ of honey produced in the country is consumed in the country as food, mainly for making refreshments and medicine - with only 5\% of honey exported' (ITC, 20I5:5).

Honey from Tanzania is in high demand in many countries (ITC, 2015, MMA, 2007), and Tanzania is the largest honey supplier to the European Union (ITC, 2015). This is because Tanzanian honey is known for its natural organic state (BTC, 2013, MMA, 2012). The availability of unique plants and vegetation including Moringa (Moringa oleifera), Clove (Syzygium aromaticum), Cinnamon and Neem (Azadirachta indica) which have therapeutic properties, adds to the advantages of Tanzanian hive products. These plants provide both nectar and pollen which can be used to create honey and bee pollen of the highest me- 
dicinal value. This increases the potential for producing hive products that can achieve good market prices.

Moreover, with increasing interest from consumers for organic food products, it is expected that the demand for organically produced hive products will grow in the future. This undoubtedly confirms the commercialisation opportunity for beekeeping in Tanzania. However, these benefits cannot be realised if commercial tools and modern techniques are not used, and reliable and profitable markets are not reached. The activity should be turned from a local to a commercial sector through the application of appropriate methods, technologies, and techniques - and access to profitable markets.

In developing areas, rural and urban local markets have unique characteristics that include size, growth rate, competition, and opportunity for innovation (Chikweche, 20I3; Jun et al. 20I3; Majumder, 2012; Pervez, 2013). This presents an excellent opportunity for business growth for rural and urban businesses, including beekeeping. Surprisingly, beekeeping markets are still under-served or yet to be explored. They are served by a sector that is poorly organised, functions through disorganised channels (Baltazar 20I3; Jiwa, 20I3; Matavel, 20I4), with uncoordinated actors. Commercialisation practices are still inefficient, weak, and disorganised. Beekeeping still depends on traditional methods, and these make the sector less productive, with low-quality products, and unpredictable markets.

'The beekeeping sector in Tanzania is currently being handled by individual beekeepers that lack adequate finance and appropriate beekeeping skills. There is no organized marketing system for both local and foreign markets to encourage the development and expansion of the industry' (ITC, 2015:5).

All these concerns make people believe that beekeeping cannot become commercial, and that it must remain a part-time activity for poor and old rural people. Similarly, it raises some questions that need to be answered. If the beekeeping market is still untapped and its potential is not fully utilised (ITC, 20I5; MMA, 2007; SNV, 2009) why do beekeepers still complain about the market? If there is good forage for quality honey, why is quality still an issue? How can the productivity, quality, and marketing of bee products be improved? The main question, however, is about understanding the constraining factors for the commercialisation of beekeeping: and converting the large observed beekeeping potential into profitable and attractive markets.

Therefore, by using the theory of constraints approach, this study explores the potential limitations for commercial beekeeping in Tanzania, and specifically, the Mvomero district.

\section{Literature review}

\subsection{Theoretical review}

This study analyses the constraining factors for commercial beekeeping in Tanzania and we make use of the theory of constraints (TOC) to analyse the phenomenon. This theory has been commonly known as a management approach that aims to initiate and 
implement breakthrough improvements by focusing on a constraint that prevents a system from achieving a higher level of performance (Sematupang et al. 2004). TOC views weak chains of activities (called constraints) as limiting any manageable system from achieving more of its goals.

Goldratt (I990b), Klein and DeBruine (I995), and Dettmer (I997) state that TOC views an organisation, or a system, as a chain composed of many links or networks of chains. These links are strongly dependent on each other and all contribute to the system goal. Therefore, if the system fails to achieve its goal, the main reason will be the underperformance of at least one of the links, also called the weakest links (Goldrattt and Cox, 2004; Moynihan, 20I4; Simatupang et al. 2004). This is to say that, the overall performance of a system is restricted by its weakest link because the chain is only as strong as its weakest link. To improve the performance of a system, the first step must be to identify the system's weakest link (called a constraint).

Identifying the weakest link in a system has been a challenge to most managers. This is due to the fact that most managers focus on visible negative effects, rather than the root cause of the problem. However, based on the underlying foundation of the theory of constraints, managers can identify the root cause of negative effects.

TOC focuses through the cause-and-effect thinking process to identify the constraints (Dettermer, 2000; Goldrattt and Cox, 2004). To improve the performance of the system, the rest of the system links will then be restructured around the identified weakest link.

The cause-and-effect thinking processes of ToC has been applied to identify, understand, and improve all systems in an organisation (Avraham, 2009). The process uses three questions (Dettermer, 2000; Goldrattt and Cox, 2004; Junior et al., 2004; Rahma, 2002): what to change; what to change into, and how to cause the change? However, the purpose of this study is to identify core problems (constraints) that limit the commercialisation of beekeeping systems. Therefore, the study is limited to the first question: what to change?

What to change? This is the first question, and first step of the TOC, and aims to define the core problems found in a system. Kingman (1996), as cited by Junior et al. (2004), points out that this step is constructed from a cross-functional logic that analyses the core problems of a system in depth. The core problem, also called core conflict, is an unresolved conflict that keeps a particular system trapped and/ or distracted in a constant contention. It is this conflict that be changed. The challenge, however, is identifying the core conflict, or answering the question: 'what to change'?

By using the TOC approach, the what to change question is answered by the construction of a current reality tree (CRT) from a list of observable symptoms (Goldrattt and Cox, 2004). CRT is a logical structure of thinking tools that depicts the reality in a given system (Dettermer, 2000; Junior et al., 2004; Rahma, 2002). CRT aims to define the core problems found in a specific system. To do this, a scientific method based on causeand-effect is used to identify the underlying common cause, and the core problems for all of the symptoms (Avraham, 2009; Dettermer, 2000; Rahma, 2002). Since this study is limited to what to change, the question, and the cause-and-effect technique will be used 
to identify the weakest link for commercialising Tanzanian beekeeping.

\subsection{Beekeeping constraints}

A constraint is anything that prevents, or limits, the system (company, organisation, enterprise or agency) from achieving its goal (Dettermer, 2000; Goldratt and Cox, 2004). It is the weakest link in a system that prevents achievement of the goals (Moynihan, 20I4). Goldratt and Cox (1992) as cited by Sumatupanga et al. (2004), defined a constraint as an element or factor that limits the system from doing more of what it was designed to do. A constraint is a core problem, or core conflict, that limits a system from achieving the best possible output from its operations.

Various studies have put forward constraints that hinder the effective development of beekeeping potential. This is summarised in Table I below. 


\begin{tabular}{|c|c|}
\hline Author (year) and Title & Constraints or Challenges \\
\hline $\begin{array}{l}\text { Abebe and Ranjitha (20II) } \\
\text { Beekeeping sub-sector challenges and } \\
\text { constraints in Atsbi Wemberta District of } \\
\text { eastern zone, Tigray Region, Ethiopia. }\end{array}$ & $\begin{array}{l}\text { I. Drought. } \\
\text { 2. Honeybee pests and disease. } \\
\text { 3. Shortage of beekeeping materials. } \\
\text { 4. Death of colony and reduction of honeybee colonies. } \\
\text { 5. Lack of skill and adequate support. } \\
\text { 6. Marketing problem. } \\
\text { 7. Shortage of bee forage. }\end{array}$ \\
\hline $\begin{array}{l}\text { Baltazar et al (20I3) } \\
\text { Potentials and Challenges of Beekeeping } \\
\text { Industry in Balang'dalalu Ward, Hanang' } \\
\text { District in Manyara. }\end{array}$ & $\begin{array}{l}\text { I. Inadequate capacity building programmes. } \\
\text { 2. Lack of customers to buy refined honey or beeswax. } \\
\text { 3. Little knowledge of honey processing. } \\
\text { 4. Lack of equipment. } \\
\text { 5. Unreliable market. }\end{array}$ \\
\hline $\begin{array}{l}\text { Bees for Development (2004) } \\
\text { Constraints to bee development. }\end{array}$ & $\begin{array}{l}\text { I. Biological constraints. } \\
\text { 2. Technical constraints. } \\
\text { 3. Trade constraints. } \\
\text { 4. Institutional constraints. }\end{array}$ \\
\hline $\begin{array}{l}\text { Bees for Development (2006) } \\
\text { The African Honey Trade: Unlocking the } \\
\text { Potential. }\end{array}$ & $\begin{array}{l}\text { I. Profitability of the honey business. } \\
\text { 2. High cost of transport and low volumes per household. } \\
\text { 3. Erratic interaction with traders. } \\
\text { 4. Beekeeping as a sector is overlooked, neglected, and attracts } \\
\text { little serious investment and support. } \\
\text { 5. Beekeepers are often more remote, less literate, have little ex- } \\
\text { perience with traders and businesses, and willing to take fewer } \\
\text { financial risks than other farmers. } \\
\text { 6. Exploiting the potential of high-value niche products. } \\
\text { 7. Fair trade certification and organic certification. }\end{array}$ \\
\hline $\begin{array}{l}\text { Birhan et al (2015) } \\
\text { Assessment of Challenges and } \\
\text { Opportunities of Bee Keeping in and } \\
\text { Around Gondar }\end{array}$ & $\begin{array}{l}\text { I. Shortage of bee forage and rainfall. } \\
\text { 2. Agro-chemical poisoning. } \\
\text { 3. Pests and predators. } \\
\text { 4. Absconding. } \\
\text { 5. Scarcity of beekeeping equipment. Lack of honey storage facili- } \\
\text { ties. } \\
\text { 6. The absence of policy in apiculture sector. }\end{array}$ \\
\hline $\begin{array}{l}\text { Guyo and Solomon (2015) } \\
\text { Review of Beekeeping Activities, } \\
\text { Opportunities, Challenges and Marketing } \\
\text { in Ethiopia }\end{array}$ & $\begin{array}{l}\text { I. Drought. } \\
\text { 2. Pests, predators, and honeybee diseases. } \\
\text { 3. Pesticide poisoning. } \\
\text { 4. Low hive occupancy rate and absconding. } \\
\text { 5. Lack of modern beekeeping equipment and materials. } \\
\text { 6. Lack of honey storage facilities. } \\
\text { 7. Poor extension service and lack of appropriate knowledge } \\
\text { beekeeping. } \\
\text { 8. No or little involvement of women in beekeeping. }\end{array}$ \\
\hline
\end{tabular}




\begin{tabular}{|c|c|}
\hline Author (year) and Title & Constraints or Challenges \\
\hline $\begin{array}{l}\text { Hilmi et al (2012) } \\
\text { Beekeeping and Sustainable Livelihood }\end{array}$ & $\begin{array}{l}\text { I. Bee species, parasites, and diseases. } \\
\text { 2. Supply chain and market linkages. } \\
\text { 3. Quality and standards in local and international markets. } \\
\text { 4. Processing and packaging. } \\
\text { 5. Local skilled trainers. } \\
\text { 6. Gender. } \\
\text { 7. Honey collection centres and producer organisations. } \\
\text { 8. Public policy. }\end{array}$ \\
\hline $\begin{array}{l}\text { International Livestock Research } \\
\text { Institute (2013) } \\
\text { Apiculture value chain vision and strategy } \\
\text { for Ethiopia. }\end{array}$ & $\begin{array}{l}\text { I. Dependence on the technology of low productivity, resulting } \\
\text { from undeveloped research. And limited number of industrial } \\
\text { honey processors. } \\
\text { 2. Poor pre- and post-harvest management. } \\
\text { 3. Inadequate capacity building and extension service. } \\
\text { 4. Limited knowledge of modern apicultural development. } \\
\text { 5. Inadequate access to finance and beekeeping inputs. } \\
\text { 6. Lack of market information for both honey and beeswax. } \\
\text { 7. The negative impact of climate change (habitat destruction). }\end{array}$ \\
\hline $\begin{array}{l}\text { Kimaro et al (2013) } \\
\text { Modern beekeeping as an enterprise } \\
\text { for monetary benefits, environmental } \\
\text { rehabilitation, and biodiversity } \\
\text { conservation: A case study of Lushoto } \\
\text { District. }\end{array}$ & $\begin{array}{l}\text { I. Lack of or limited and unreliable market (market problem). } \\
\text { 2. Lack of beekeeping equipment and over-reliance on traditional } \\
\text { beehives. } \\
\text { 3. Stakeholders in apiculture have diverse interests in beekeeping. } \\
\text { 4. Low plant species variety and drought. } \\
\text { 5. Diversity and human settlements. } \\
\text { 6. Invasion by alien plants from settlements to nearby forests. }\end{array}$ \\
\hline $\begin{array}{l}\text { Kinati, et al (2012) } \\
\text { Opportunities and Challenges of Honey } \\
\text { Production in Gomma District of Jimma } \\
\text { Zone, South-West Ethiopia }\end{array}$ & $\begin{array}{l}\text { I. Lack of knowledge about pests and predators. } \\
\text { 2. Lack of bee forage associated with deforestation. } \\
\text { 3. Absconding. } \\
\text { 4. Application of chemicals. } \\
\text { 5. Disease. } \\
\text { 6. Poor storage facilities and extension service. }\end{array}$ \\
\hline $\begin{array}{l}\text { Match Maker Associates Limited } \\
\text { (2007) } \\
\text { Honey and beeswax value chain analysis } \\
\text { in Tanzania. }\end{array}$ & $\begin{array}{l}\text { I. Seasonality and low quality of bee products. } \\
\text { 2. Perception of honey as a medicinal product and limited aware- } \\
\text { ness of the benefits of beekeeping products among local com- } \\
\text { munities makes local markets very small and unattractive. } \\
\text { 3. Limited access to new beekeeping technologies. } \\
\text { 4. Low technology adaptation among producers and processors. } \\
\text { 5. Beekeeping dissemination technologies have not been done } \\
\text { consistently and professionally. } \\
\text { 6. Absence of standardisation and underdevelopment of bee } \\
\text { products. } \\
\text { 7. Low levels of smallholder beekeeper assets. } \\
\text { 8. Collapse of beekeeper cooperative society. Beekeeper organisa- } \\
\text { tional model not yet in place, and available models not yet fully } \\
\text { tested. } \\
\text { 9. Lack of appropriate financial service models. }\end{array}$ \\
\hline
\end{tabular}




\begin{tabular}{|c|c|}
\hline Author (year) and Title & Constraints or Challenges \\
\hline $\begin{array}{l}\text { Melhim et al (2010) } \\
\text { Beekeeping in Canada: Honey and } \\
\text { Pollination Outlook. }\end{array}$ & $\begin{array}{l}\text { I. Pests and diseases, and inadequate urban extension services. } \\
\text { 2. Agriculture (negative externalities - pesticides, land clearing). } \\
\text { 3. Destruction of natural habitat and associated biodiversity. } \\
\text { 4. Climate change, and } \\
\text { 5. Aggressiveness due to cross-breeding with Africanized bees. }\end{array}$ \\
\hline $\begin{array}{l}\text { Match Maker Associates Limited } \\
\text { (20I2) } \\
\text { Kigoma Honey Subsector and Value Chain } \\
\text { Analysis Report. }\end{array}$ & $\begin{array}{l}\text { I. Input supply - low quality of beehives, limited access to equip- } \\
\text { ment. } \\
\text { 2. Production and management-limited knowledge and skills, } \\
\text { long distance to apiaries, herder conflicts, tobacco farming, and } \\
\text { bush burning. } \\
\text { 3. Market access - limited access to assured markets and niche } \\
\text { markets. } \\
\text { 4. Beekeeper organisation and management - young or new and } \\
\text { poorly organised, legal structures, distrust among members, } \\
\text { skilled personnel. } \\
\text { 5. Product development and technology - use of traditional and } \\
\text { underdeveloped technology. } \\
\text { 6. Policy and regulations. } \\
\text { 7. Access to financial services. } \\
\text { 8. Transversal or cross-cutting themes: environment, climate, and } \\
\text { gender. }\end{array}$ \\
\hline $\begin{array}{l}\text { MINAGRI/RARDA (2006) } \\
\text { National Beekeeping Strategic Plan } \\
\text { Document 2007-2012, Tanzania }\end{array}$ & $\begin{array}{l}\text { I. Lack of adequate technical skills. } \\
\text { 2. Poorly coordinated and managed producer organisations. } \\
\text { 3. Lack of centralised statistics and information. } \\
\text { 4. Lack of finance. } \\
\text { 5. Clarity of roles and responsibilities of stakeholders. } \\
\text { 6. Loss of habitat for bee colonies. } \\
\text { 7. Use of chemical pesticides. } \\
\text { 8. Natural occurring activities such as a change in climatic condi- } \\
\text { tions (force majeure). }\end{array}$ \\
\hline $\begin{array}{l}\text { Munthali and Turner (20II) } \\
\text { Importance of Epidemiol-surveillance: the } \\
\text { example of Botswana }\end{array}$ & $\begin{array}{l}\text { I. Human resources: lack of specialised training in apiculture; } \\
\text { insufficient numbers to serve whole country. } \\
\text { 2. Further promotion of bee-keeping as a sustainable and profit- } \\
\text { able enterprise. } \\
\text { 3. Lack of legal framework governing the sector. } \\
\text { 4. Lack of scientific research on apiculture. } \\
\text { 5. Outdated beekeeping legislation. } \\
\text { 6. Lack of awareness of benefits of beekeeping among the public. } \\
\text { 7. Lack of gazetted areas for beekeeping use. } \\
\text { 8. Pests and diseases threats. }\end{array}$ \\
\hline
\end{tabular}

Table 1: Beekeeping constraints from different studies. Source: compilation of the literature by the authors.

Different studies have pointed out several issues or factors that seem to be responsible for the underperformance of the beekeeping sector. One study suggested four constraining factors (Bee for Development, 2004) while other studies pointed to at least nine factors (MMA, 2007; and Nyatsande et al. 2014). 
However, within the theory of constraints (TOC), a core principle is that there are only a few constraints (Goldratt and Cox, 2004). At least one constraint in any given system could either be internal or external to the system (Dettemer, 2000; Goldratt and Cox, 2004). An internal or physical constraint is in evidence when the market demands more than the system can deliver. And an external or policy constraint exists when supply exceeds demand.

TOC analyses the weakest link of a system based on supply and demand (Dettemer, 2000). When demand is higher than supply, the implication is that the system is not performing well internally. Therefore, there will always be a deficit in the market. All products will be consumed without satisfying market needs. If this condition exists in a particular market system, then the weakest link or constraint is inside the system. On the other hand, an external constraint exists when the system produces more than the market will bear, supply exceeds demand. The implication here is that the system is functioning well internally, but external factors are limiting it from achieving its goals. In this situation, the weakest link is external to the system.

In beekeeping, it is evident that demand for hive products exceeds supply, and beekeeping potential is not yet full tapped (Kimaro et al., 20I3; MMA, 20I2; Pinda, 20I4). Similarly, demand for hive products in both local and international markets is higher than what the sector can supply (ITC, 20I5). It is therefore obvious that beekeeping constraints should be observed from inside the system. In this case, all the factors responsible for non-performance of beekeeping systems in Table I should be grouped into internal and external categories. Internal factors include system resources, culture, and design. While external factors include political-legal, economic, social-culture, technology, and environmental elements. This is shown in Table 2 below. 


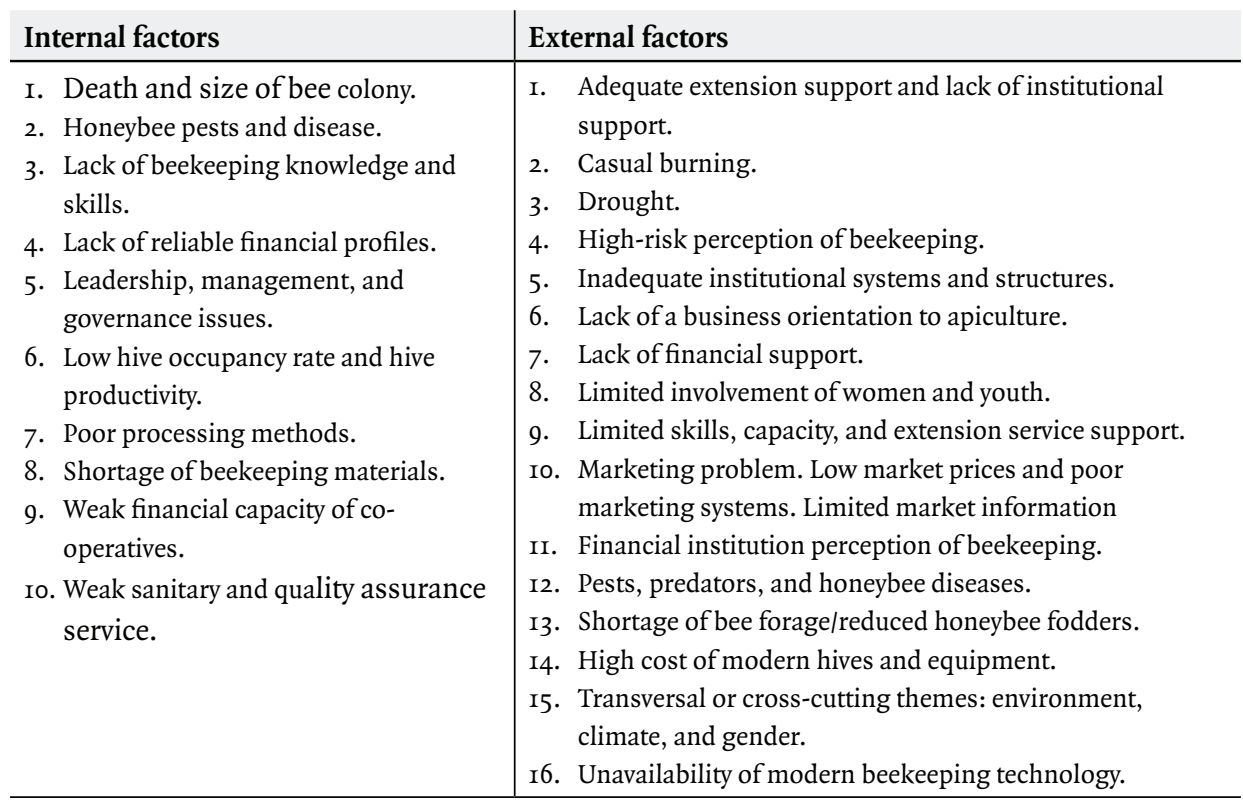

Table 2: Internal and external constraining factors for commercial beekeeping.

There are many external and internal factors responsible for the under-performance of beekeeping. The core principle of TOC says that there are few (rather than dozens) of constraints in a system. Similarly, some of the constraints mentioned are indicators/ symptoms rather than core problems. For example, the death of bees is a symptom of disease and pests; and a declining colony size is a symptom of a lack of fodder or old queens. Therefore, it is important to study these internal factors under the TOC lens so that a core problem can be identified.

\section{Approach and methodology}

The study was conducted in the Mvomero District, one of the six districts of Morogoro region (Mvomero District Council [MDC], 2012). With an estimated population of 312,I09 (I57,266 female - URT, 2013), the district covers 7,325 km² (MDC, 2012) with four ecological zones suitable for beekeeping (highland, miombo woodland, mountainous, and the Savannah River basin) (MDC, 2012; Wasenna et al. 2013). The area has considerable beekeeping potential and so was ideal for the study.

Record keeping is one the most challenging issues when researching in developing areas. This study faced the same challenge. At the beginning of the study, there was no reliable information about beekeepers, beekeeping groups, or potential partners, and beekeeping actors in the study area. After visiting Mvomero district council, and Tanzania Forest Services at Turiani and Mkindo offices, we were convinced that we needed to build our own beekeeping study database. Despite the fact that we used triangulated sampling techniques, snowball sampling was the starting point. 
'Snowball sampling is commonly used when it is difficult to identify members of the desired population. You, therefore, need to: first, make contact with one or two cases in the population. Secondly, ask these cases to identify further cases. Then ask these new cases to identify further new cases (and so on). Lastly, stop when either no new cases are given, or the sample is as large as is manageable. The main problem is making initial contact. Once you have done this, these cases identify further members of the population, who then identify further members, and so the sample snowballs' (Saunders, Le wis and Thornhill 2009).

To overcome the limitation of this technique (namely, making the initial contact), we started the survey by asking the village or ward office if they knew anybody keeping bees. From the official and social information we obtained from the office, we approached the samples, and so the sample snowballed.

After surveying 120 villages from four divisions (Nyandira, Mlali, Mvomero, and Turiani) we had a list of 68 units as our study population. This list included interested individuals who either want to keep bees, or engage in beekeeping further along the value chain. We also had a list of beekeepers, beekeeping groups, and actors or organisations involved in beekeeping.

A number of factors were used to determine whether or not an actor was included on the final list. After taking into account the number of beehives, and size of the investment measured in monetary value, availability of bee fodder, legal status (formal or informal), and commitment to beekeeping, the list was reduced to I7 beekeepers and beekeeping groups. The qualified units were contacted so that we could obtain their agreement to participate in the study. However, after some discussion with the selected samples, surprisingly, two units from Lungo and Mziha villages were reluctant to participate. Also, six units were disqualified on humanitarian grounds. Finally, nine producer groups with more effective and committed beekeepers and six beekeeping experts (from the Mvomero district council (2), Morogoro region (I), SIDO (I) and Sokoine University of Agriculture (2)) were included in the study.

Using triangulated data collection techniques (Eisenhardt, I989; Crewell, 2003; Crewell, 2009; Yin, 20I4), data was collected until saturation. The first technique was a personal interview. An unstructured interview guide was used with i 8 selected beekeep ers. These beekeepers belonged to the six selected beekeeping groups. Their selection, however, was based on beekeeping experience, positions they hold in a group, level of education, age, and gender. The motivation of the study was explained to the interviewee, and whenever possible, voice recording and picture taking was agreed.

Thereafter, the observation technique was used. It was used firstly to bridge the gap between information collected through interviews, and reality in the market. For example, an interviewee might say that they have 15 occupied hives. But the average amount of honey harvested per season may not reflect the number of hives. The observation technique is important to understand what is actually happening on the ground. Secondly, the observation technique was used so that the study could benefit from the strength of the technique in qualitative data collection. Therefore, this technique was used to capture the information on the number of hives in apiaries, occupancy rate, pest and predator 
management, and forage assessment. Later, however, the observation was extended to the harvesting and processing of hive products. Pictures, short clips, and note-taking were used to capture information.

After collecting data through observation, we found a very large variation in information validity and reliability. Therefore, we employed group interviews and focus group discussions to obtain valid and reliable data. Supported by the observation and prior interviews six beekeeping groups were interviewed. The purpose of the interview was explained to the group. Whenever possible, the interview was recorded and photos were taken.

Descriptive statistics and current reality trees (CRT) of the thinking process (TP) approach (Dettemer, 2000; Goldratt and Cox, 2004) were used for data analysis. Descriptive statistics were used to capture demographic elements on the beekeeping practices of respondents, while, CRT was used to identify the core constraints (Junior, et al. 2004; Shams, 2002) of beekeeping commercialisation in Tanzania. The cause-and-effect technique of the CTR was used to identify the factors that were symptomatic rather than core constraints. The findings are presented in the next section.

\section{Findings and discussions}

Information collected from actors and participants in the beekeeping sector shows that constraints for commercialisation of beekeeping arise from several factors: mostly external, and related to honeybee behaviour. Most problems mentioned include a shortage of types of equipment and tools (beehives, extractors, and packaging materials), market saturation during harvest season, and poor marketing infrastructure. Moreover, inadequate beekeeping knowledge and skills, lack of storage facilities, pest and predators, theft, forest fire, and land conflicts were found to adversely affect beekeeping.

This section presents the findings and discussion of the study. However, the presentation of the findings will be made with the discussion in order to stay focused on one factor at a time. The discussion is centred on the cause-and-effect technique on the impact of the factor on beekeeping commercialisation.

\subsection{Lack of capital and financial services}

The study findings reveal that most beekeepers and beekeeping groups are willing to invest in the activity, but they are limited by their financial means. This concern was also raised during personal interviews, beekeeping group interviews, and beekeeper focus group discussions. They pointed out that they do not have the funds or access to financial services for beekeeping investment. 
'Without funds what can you do? Everything needs money. And you can imagine in our environment getting money is not an easy task. But in beekeeping activities, you cannot buy good hives or beekeeping tools and equipment without money. For example, a good bee suit costs up to Tshs 200,000. Where can a rural beekeeper get such an amount of money just for one suit? Also, without money, you cannot attend workshops, seminars, or exhibitions. Some months back we were invited by SIDO to attend a beekeeping workshop in Morogoro town. But we failed to go because we had no money to cover the traveling costs. We think money is the number one constraining factor for commercial beekeeping'. Beekeeper focus group discussion.

This finding, however, contradicts findings from joint stakeholders (beekeepers, beekeeping actors, and supporting units) in the focus group discussion. For example, one company, which supplies beekeeping tools and equipment, said that they have tools and equipment, yet beekeepers are reluctant to borrow them. An expert from the MNRT said that at the national level, it has invested more than Tshs 600 million over two years. All the money was spent on tools and equipment, training, and quality assurance.

This study was, however, limited to analysing the constraining factors for beekeeping commercialisation in Tanzania. Investigating where the money was spent, or exploring beekeeping financing strategies were beyond the scope of this work.

\subsection{Honeybee diseases, pests, and predators}

Beekeepers explain that ants, wax moths, wasps, bee-eater birds, spiders, small hive beetles, snakes, and lizards are the most harmful pests. Respondents confirmed that they had observed ants, wasps, and spiders inside their beehives. They also saw their honeybee colonies threatened by ants and wax-moths. During data collection observation through beehive and apiary inspection, snakes and lizards were seen in hives in two beekeeping groups in the Turiani area. One beekeeping group also admitted that their bees may be suffering from a disease that kills the brood. During the rainy season, they observed dead broods in some of their hives. However, the beekeepers were not able to identify the disease nor its causes. Moreover, humans are reported to be the most dangerous predator: hives were destroyed in Wami-Dakawa, burned in Turiani, and colonised hives and honey were stolen, and other destructive acts. This has resulted not only in the destruction of bee colonies, but also beehives, and apiaries.

By using the thinking process in the current tree reality, it can be observed that pests, diseases, and predators are caused by a lack of knowledge on pests, diseases, and predator control; and poor apiary management practices. For example, if apiary inspection is done properly, and appropriate steps are taken to control pests and predators, this should not be a problem for beekeeping commercialisation. It should, however, be noted that using the cause-and-effect approach, these pests and predators result in the death of the bee colony, prevent hive colonisation, or decrease the size of the bee colony. However, the two factors most affecting productivity are absconding and beehive occupancy rates. 


\subsection{Absconding, swarming and migration}

Absconding and migration occurs when honeybee colonies abandon their habitat or beehives. Swarming occurs naturally when a bee colony divides to make new colonies. Swarming is a very important process for increasing the number of colonies. However, it affects the production of honey because during the division the swarm leaves behind a small bee colony. While swarming is a natural bee behaviour, absconding and migration mostly occur when bees are disturbed. Some of the reasons for absconding and migration include a decrease in bee fodder or forage, and the incidence of bee diseases, pests, and predators. Other reasons include poor harvesting practices, sanitation problems, changing weather conditions, and fire.

The study findings, however, show that absconding and migration of honeybee colonies in Mvomero are mostly caused by the poor and dirty conditions of the apiaries, poor harvesting practices, and pests and predators. For example, in Kwelikwiji and Kwamayambi, the absconding incidence is more prevalent in traditional hives than in top bar hives because of poor harvesting practices. Open fire instead of smoke is mostly used to control bees during harvesting, and all combs - honey, brood, and pollen combs - are taken out of the hive. This harvesting practice kills a large part of the colony and also leaves the colony without food. This situation disturbs the colony and hence it absconds or migrates.

Through observation, it is revealed that absconding and migration of honeybee colonies are caused by poor apiary management and lack of harvesting knowledge and skills. If apiaries are well managed, then the factors that cause absconding can be controlled. Therefore, appropriate beekeeping knowledge and skills, and proper apiary management practice, can be used to effectively reduce the damage caused by these behaviours.

\subsection{Occupancy rate}

Occupancy occurs when the honeybee colony inhabits the beehive. Usually, small groups of bees first inspect empty hives, then select one, after which the whole colony migrates to the selected hive. The occupancy rate is the number of inhabited hives in an apiary expressed as a ratio (percentage). For effective and efficient beekeeping, the ideal occupancy rate is at least $75 \%$. The study occupancy rate is as shown in Table 3 below. 


\begin{tabular}{r|l|r|r|r|r} 
S/No. & Beekeeper Name & $\begin{array}{l}\text { Number } \\
\text { of Hives }\end{array}$ & $\begin{array}{l}\text { Top-Bar } \\
\text { Hives }\end{array}$ & $\begin{array}{l}\text { Occupied } \\
\text { Hives }\end{array}$ & \multicolumn{2}{l}{$\begin{array}{l}\text { Occupancy } \\
\text { Rate }\end{array}$} \\
\hline I & Gelageza - Konga & 45 & 45 & 19 & $42.22 \%$ \\
\hline 2 & Hemed -Kanga & 96 & 96 & 4 & $4.17 \%$ \\
\hline 3 & VoiceWomen - Dakawa & 30 & 30 & 25 & $83.33 \%$ \\
\hline 4 & Jikomboe - Kilimanjaro & 46 & 46 & I2 & $26.09 \%$ \\
\hline 5 & UWAMI - Diyongoya & 46 & 30 & 38 & $82.61 \%$ \\
\hline 6 & Umoja - Kwelikwiji & 27 & 15 & 19 & $70.37 \%$ \\
\hline 7 & Dickson - Mkindo & 56 & 16 & 24 & $42.86 \%$ \\
\hline 8 & UPAPEMA - Peko & 48 & 48 & 6 & $12.50 \%$ \\
\hline 9 & Fatuma - Kwamayambi & 20 & 0 & I2 & $60.00 \%$ \\
\hline Total & & $\mathbf{4 1 4}$ & $\mathbf{3 2 6}$ & $\mathbf{1 5 9}$ & $38.41 \%$ \\
\hline
\end{tabular}

Table 3: Beehive occupancy rate in Mvomero district.

Mvomero has many bee hives, but findings show that the average apiary occupancy rate is less than 40 percent. Surprisingly, the group with a $4 \%$ occupancy rate is situated near the Mkingu Nature Reserve in Kanga Village. This forest has a plentiful supply of bee fodder and there are many bee colonies nearby.

Similarly, the study shows that farming activities, fire burning, herding, honeybee predators, beehive quality, and poor harvesting methods are the factors causing low occupancy rates. Another factor responsible for low occupancy rate is over-reliance on local or natural colonisation processes. Beekeepers simply bait their hives, and wait for a bee colony to inhabit it naturally. This is because most beekeepers have an insufficient knowledge of hive colonisation techniques such as swarm catching and colony division.

However, most beekeepers do not see the low occupancy rate as a problem. They are happy to have a good number of beehives - whether occupied or not. However, variations in occupancy rate do greatly affect beekeeping. When a beehive is not colonised, there is no beekeeping to be done. When occupancy rates are low, beekeeping tools and equipment are not used, or not fully utilised, apiary productivity falls, and the business itself becomes less productive. It is therefore important to improve the occupancy rate so that beekeeping can be productive and profitable.

The best way to improve the occupancy rate is to ensure that beehives are clean, visible, and well placed to allow easy inhabitation. Occupancy rates can be increased through colony division, queen rearing, and swarm catching. But these techniques require skills and good working tools that most beekeepers do not have. Therefore, it is important to upgrade the technical and management skills of beekeepers so that they can improve occupancy rates. 


\subsection{Poisonous nectar and water sources}

Some nectar, pollen, and water sources from plants, are toxic to bees, and honey produced from such sources may be toxic to humans. In some cases, poisonous materials come from polluted sources that are the result of human activities (such as agriculture and industrial waste disposal).

In this study, one group reported a decline in colonies as a result of bee deaths from palm wine. During palm wine harvesting, bees smell the wine, which is sweet, and enter the harvesting container to suck the liquid. Many bees die either in the containers as a result of drowning, or in the hives due to the effects of the wine. This affects beekeeping productivity and leads to a decline in the colonies; and in some cases, the honey smells of palm wine (which reduces its quality). We also observed that in areas where horticulture is intense, bee colonies and beekeeping are limited.

In this case, planting for the bees (i.e. forage making) and appropriate site selection are management practices that can reduce or remove this limitation. Beekeepers need to improve their forage and acquire the appropriate skills for site selection and apiary location.

\subsection{Beekeeping inputs}

Inputs for beekeeping activity include all the materials, types of equipment, and tools that are used in the beekeeping value chain. This includes beehives, harvesting and processing equipment, and packaging materials. If beekeepers have limited access to quality inputs, or if sub-standard inputs such as fake bee suits and smokers perform badly, their ability to work with bees is limited. Also, poor quality materials cause resistance to the adoption of modern beekeeping techniques, which will consequently reduce the potential for commercial beekeeping.

The study findings show that beekeeping in Mvomero is constrained by access to quality beekeeping inputs. Access to commercial hives, harvesting, and processing equipment are the inputs most constraining beekeeping. Some of the available beekeeping tools and equipment are of low quality. Because of limited access to modern types of equipment and tools, traditional beekeeping methods are still frequently used. For example, the study findings show that about $75 \%$ of beehives are traditional hives such as pots, logs, and box hives. Moreover, most of the top-bar hives in use have no queen excluder.

'When we started beekeeping, Oxfam International supplied us with some bee suits and smokers. But these tools were of very poor quality. We attempted to go for harvesting, but the bees were entering the suits through some holes in a veil. Also, the suits were made up of very light materials such that, bees could still sting you through a suit. Similarly, smoke was coming out from different sides of the smoker. We ended up running away and leaving the hives down' - group interview response.'

One beekeeping group, for example, has kept bees ( 46 beehives, with 38 colonised) for about two years without harvesting because they lacked harvesting tools and equipment. They once tried to hire harvesting suits from neighbouring groups, but they re- 
ceived very poor quality suits. When they went harvesting, it was not possible to work with suits of such poor quality.

Similarly, we observed that during harvesting, processing, and packaging most beekeepers use local types of equipment and tools. In most cases, they use recycled materials or containers for storage and packaging. No beekeeping group, or beekeeper, is using a label or labelled containers to sell their honey. This affects the marketing of their products. To access reliable and profitable markets, using accepted containers and labelling is important.

The thinking process shows that the main problems can be summarised as follows: firstly, the unwillingness of beekeepers to invest in beekeeping inputs; secondly, lack of capital for investing in beekeeping inputs; thirdly, lack of appropriate knowledge on the importance, efficiency, and effectiveness of using appropriate inputs in beekeeping. We draw this conclusion after the observation that, despite commercial inputs being available in the market, beekeepers were reluctant to acquire them. Some beekeepers are not even aware that such tools and equipment are available. It is therefore important to create awareness about the significance of using commercial tools.

\subsection{Knowledge and skills}

Beekeeping is a knowledge-intensive activity as it requires appropriate beekeeping knowledge and skills to turn it into a commercial business. In modern or commercial beekeeping, appropriate knowledge and skills on queen rearing, colony division, apiary management, beehive product harvesting, processing, and honey handling are necessary; a lack of these leads to inefficiencies, poor occupancy rates, and poor quality products. The study findings on beekeeper educational levels and experience in beekeeping are summarised in Table 4 below. 
Education Level

\begin{tabular}{|c|c|c|c|c|c|}
\hline & & Frequency & Percent & Valid percent & Cumulative percent \\
\hline \multirow[t]{4}{*}{ Valid } & Basic or Primary & 67 & 78.8 & 78.8 & 78.8 \\
\hline & Secondary & I4 & 16.5 & 16.5 & $95 \cdot 3$ \\
\hline & Tertiary & 4 & $4 \cdot 7$ & $4 \cdot 7$ & 100.0 \\
\hline & Total & 85 & 100.0 & 100.0 & \\
\hline \multicolumn{6}{|c|}{ Experience in Beekeeping } \\
\hline & & Frequency & Percent & Valid percent & Cumulative percent \\
\hline \multirow[t]{3}{*}{ Valid } & $<5$ years & 52 & $6 \mathrm{r} .2$ & $6 \mathrm{r} .2$ & $6 \mathrm{I} .2$ \\
\hline & 6-1o years & 33 & 38.8 & 38.8 & 100.0 \\
\hline & Total & 85 & 100.0 & 100.0 & \\
\hline
\end{tabular}

Table 4. Education and experience of beekeepers in Muomero district.

The study shows that about $78 \%$ of beekeepers have only the basic or primary education. This level of education is centred on reading, writing, and counting skills. Similarly, about $6 \mathrm{r} \%$ are novice beekeepers: they are still very new to the sector, with less than five years of beekeeping experience. This indicates that their beekeeping knowledge is very limited. They mostly rely on traditional knowledge and skills inherited from neighbours. Similarly, beekeeping experts confirmed that limited beekeeping knowledge and skills, and over-reliance on local experience, have limited progress in the sector.

'During our time, we tried to make sure that at least every district has a well trained and experienced beekeeping officer. But, transferring technical knowledge and skills continues to be a problem because most of our beekeepers are poor rural people who depend on their indigenous inherited knowledge and experience in beekeeping. This has affected not only the resistance to technology adoption, but also failed to improve quality and productivity of the sector. I think it is important for scholars, and training institutions to look at the sector, and prepare tailor-made courses to bridge the knowledge gaps in beekeeping,' Hon. Mizengo P.K. Pinda, Prime Minister (2007-2015) the United Republic of Tanzania, and a beekeeper, as interviewed on 7 March, 2017.

Similarly, study findings show that most beekeepers have limited knowledge about core beekeeping activities. For example, most beekeepers think that beekeeping is about owning beehives. It is about putting the hive on a tree, waiting for the honeybees to colonise it, and then harvesting. Therefore, a beehive is, according to them, the most important piece of equipment in beekeeping. This is not the case. Beekeepers do not always appreciate that having bee colonies is more important than having beehives. Honey can be produced without beehives, but cannot be produced without honeybees. about it can also be the case that beekeepers neglect the proper management of beekeeping activities, such as colony manipulation, foraging for the bees, and apiary management. 
Beekeepers should know how to improve the productivity and quality of hive products. They should also plan on how to work within a larger beekeeping value chain so that they can be more productive and profitable.

\subsection{Different reasons for beekeeping}

The profit motive is among the important factors that enhances business success. In the beekeeping sector, most beekeepers keep bees for two key reasons: environmental conservation and additional income.

Those who are beekeeping for environmental conservation are very reluctant to see beekeeping progress. They care little about beekeeping profits - providing their conserved areas are safe. For example, one group in Pekomisegese village is beekeeping for environmental conservation. They have 48 top-bar hives located in the area. The occupancy rate is less than $\mathrm{I}_{2} \%$ and they have not harvested for more than two years, and no one seems to care much about this. They are simply content that the area is not burnt, trees are not cut, and vegetation is doing well. For them, bees are used to threaten and chase people who cut trees.

Similarly, when beekeepers engage in beekeeping with the expectation of earning money, and then experience challenges or difficulties in acquiring bee products, and selling to markets, they become frustrated, and most decide to abandon their projects.

'When we started the beekeeping project, we expected that one hive could give up to $15 \mathrm{~kg}$ per harvest, which is about Tshs 150,000 at market prices. But none of the beekeepers told us about additional costs and activities involved in beekeeping. When we went harvesting, we got less than an average of $5 \mathrm{kgs}$ per hive. At first, we thought that someone has stolen our honey, but we later realised that the yield is an average hive production in our apiary. Selling the honey was another nightmare. So in the end, no one wanted to visit the apiary. It's now three years since we last harvested', - KAECO, Kanga village.

\subsection{Recordkeeping}

In a business without records, a loss can occur without awareness. The lack of records showing apiary improvement trends, performance (occupancy and harvesting), or income and profits from beekeeping deters financial institutions from lending to beekeepers - and also limits beekeepers from monitoring performance.

During the study, it was observed that no beekeeper or beekeeping group has any records or documentation of beekeeping. The beekeepers have not recorded harvests, apiary progress and trends, nor finances. This means beekeepers cannot manage their businesses. It is very important to have records on apiary progress, hive performance, traceability, finance, harvesting, and sales so that over-performing and under-performing areas can be identified.

This lack of recordkeeping is however caused by limited business management knowledge and skills. Therefore, this element is not assumed to be a limitation of beekeeping - but rather a managerial issue. 


\subsection{Lack of beekeeping business orientation}

To commercialise the beekeeping sector, potential actors must consider it as a business and a profitable sector - rather than as a unit supporting a prime sector. But we have found that beekeeping tends to be considered as a supporting, secondary, or part-time economic activity. For example, the ministry responsible for beekeeping, the Ministry of Natural Resources and Tourism, considers beekeeping as a non-commercial activity for forest conservation (MNRT, I998; Pinda, 2014). And for beekeepers, it is a secondary or part-time activity for obtaining extra income that is carried out after completing other basic activities. This approach to beekeeping means that the beekeeping sector is perceived as more of a social activity than a business.

From the findings, ten constraining factors for commercialization of beekeeping sector in Tanzania are identified. However, most of the factors are symptoms of another factor. For example, absconding is a caused by poor harvesting, pests and predators. Also, poor quality is caused by lack of beekeeping tools and equipment. The cause and effect of these factors can be summarized as in figure I below. 


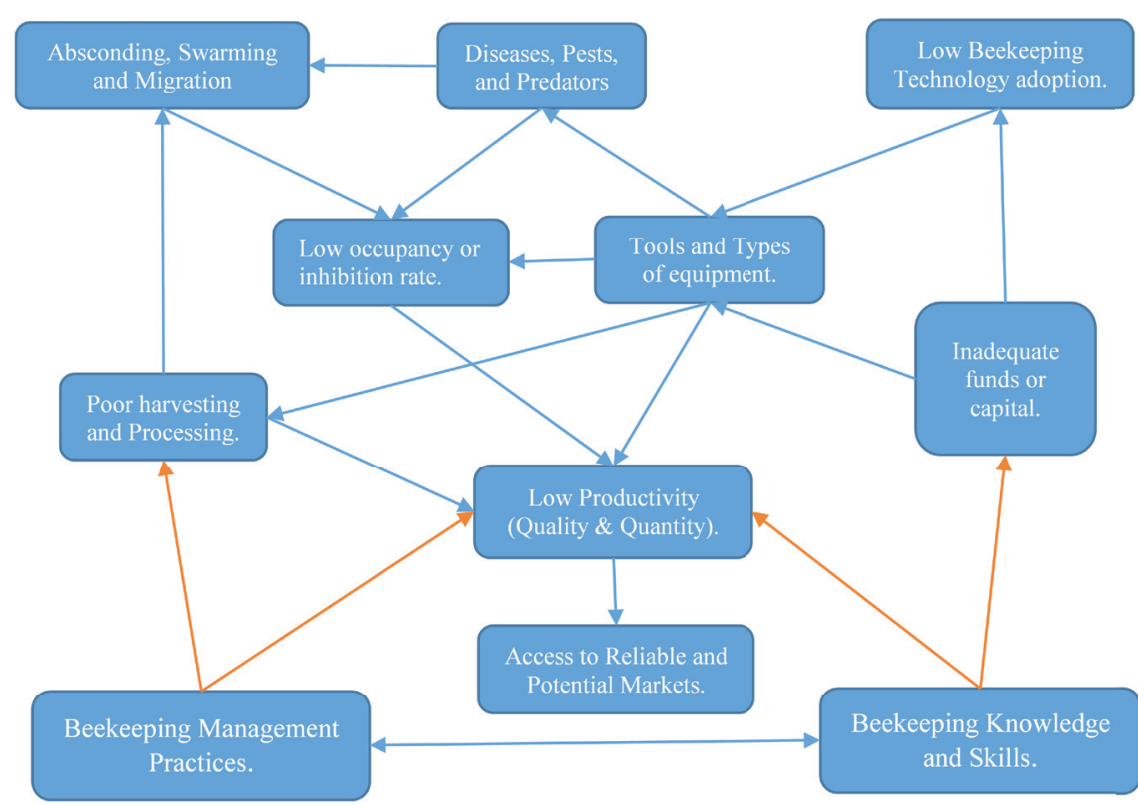

Beekeeping management means doing the following activities:

1. Foraging management: site selection, planting for the bees.

2. Hive sitting or placement and baiting: (how to attract bees in a hive).

3. Hive colonization: buying colonies, catching swarms, baiting, colony manipulation.

4. Apiary Management: hive inspection, diseases, pests and predators control, colony division and unification, re-queening and de-queening, supplementary feeding (sugar syrup), and apiary cleaning.

5. Production and Products management: record-keeping, harvesting, processing, and packaging.

Beekeeping knowledge and skills include the technical, managerial, attitude and social-cultural aspects of beekeepers towards the beekeeping activity

Figure 1: the cause-and-effect relation from the current reality tree analysis.

Access to reliable and profitable markets is the prime objective in developing commercial beekeeping. However, these markets can be reached through improved productivity and quality of beekeeping activities. Following the cause-and-effect of these factors, two issues affect the rest of the factors: management practices, and beekeeping knowledge and skills.

\section{Conclusion and implications of the study}

Despite repeated warnings that the greatest hindrance to the growth and development of beekeeping as a commercial business in Tanzania is the lack of beekeeping expertise (knowledge and skills) and business management practices, shortfalls in these two key areas continue to be core constraints. These two factors remain unaddressed as 
many efforts are directed towards tackling the symptoms, and not the root cause - numerous projects and potential stakeholders in the beekeeping sector have addressed the effects, or the outcomes, rather than the root causes. Therefore, through the cause-andeffect technique from the theory of constraints, efforts should be directed to address the key issues.

Despite the constraints currently facing beekeeping in Mvomero, there are still huge commercialisation opportunities. If the appropriate beekeeping knowledge, skills, and management were practiced, most of the constraining symptoms could be managed. Similarly, beekeeping competence in terms of skills, requirements, knowledge, and producer organisations should be strengthened through collection centres. Finance should be accessible, beekeeping tools should be made available, and access to profitable markets should be facilitated. Such measures will make commercialisation possible and help realise the social-economic potential of beekeeping.

\section{Limitation and areas for further studies}

This study was conducted through the theory of constraint lens. This theory aims at answering three important questions: what to change? what to change to? and how to cause the change? However, this study focused on analysing the factors responsible for the poor level commercialisation of beekeeping in Tanzania. It is therefore important to acknowledge that the study was limited to answering the first question only. In this regard, future studies may consider answering the remaining two questions of the theory of constraints. In addition, this study observed that the commercialisation of beekeeping should start by improving productivity, and productivity can be improved by using appropriate technology. However, technology adoption rates are very low. Therefore, future studies should investigate constraints on technology adoption (and especially commercial top-bar hives).

\section{References}

Abdu, M., Al-Samie, M., A., (2012). Studies on Bee Venom and Its Medical Uses. International Journal of Advancements in Research \& Technology, Vol. I, Issue2, July-2012 ISSN 2278-7763.

Abebe, W., and Ranjitha P., (20II). Beekeeping sub-sector challenges and constraints in Atsbi Wemberta District of eastern zone, Tigray Region, Ethiopia, Journal of Agricultural Extension and Rural Development, Vol. 3(I), pp. 8-I2, January $201 \mathrm{I}$.

Avraham, Y., (2009). Theory of Constraints and its Thinking Processes: A Brief Introduction to TOC, AGI - Goldratt Institute, New Haven, Connecticut 065II USA.

Baltazar M.L. Kianga J., and Mwabless N. M, (2013). Potentials and Challenges of Beekeeping Industry in Balang'dalalu Ward, Hanang' District in Manyara, Kivukoni Journal Vol. I No. 2, 2013: 75-93.

Bees for Development,(2004). Constraints to bee development, Bees for Development Journal 72, 2004, 3. (2006). The African Honey Trade: Unlocking the Potential, United Nations Conference On Trade And Development UNCTAD Expert Meeting "Enabling Small Commodity Producers In Developing Countries To Reach Global Markets" Organized by UNCTAD Commodities Branch Observer Presentation on II-I3 December 2006.

Birhan M, Selomon S, and Zebene G, (2015). Assessment of Challenges and Opportunities of Bee Keeping in and Around Gondar, Academic Journal of Entomology 8 (3): I27-I3I, 2015. 
BTC Tanzania, (2007). Better Income Through Beekeeping, Project on Development and Improvement of Processing, Packaging, and Marketing of Beeswax and other Bee Products in Rufiji, Kigoma and Kibondo districts, Tanzania, 2007-20I0.

(2012). Beekeeping Support Project in Kigoma, Dar es Salaam, Tanzania.

Cadwallader, A., Victoria, H., Santiago, I., and Evren, S., (20II). Supporting Urban Beekeeping Livelihood Strategies in Cape Town: An Interactive Qualifying Project, Polytechnic Institute, South Africa.

Collison C, H., Maryann F., and Dewey C., (2004). Beekeeping Basics, The Pennsylvania State University, United States.

Creswell, J., W., (2003). Research Design: Qualitative, Quantitative, and Mixed Methods Approaches. 2nd Edition, Sage Publications, Inc. USA.

(2009). Research Design: Qualitative, Quantitative, and Mixed Method Approaches, 3rd Edition, Sage Publications, Inc. USA.

Dettemer, H., W., (2000), Constraints Management, A paper published from a chapter in the updated 2000 edition of The Certified Quality Management Guide, Quality America, USA.

FAO, (2012). Beekeeping and Sustainable Livelihood, Rural Infrastructure and Agro-Industries Division, Rome, Italy.

Goldratt, E.M., and Cox, J. (2004). The Goal - A Process of Ongoing Improvement. Third revised edition, North River Press Publishing Corporation, Great Barrington, MA.

Guyo, S., and Solomon, L., (2015). Review on Beekeeping Activities, Opportunities, Challenges and Marketing in Ethiopia, Journal of Harmonized Research in Applied Sciences, 2015, 3(4), 20I-2I4.

Hilmi, M, Nicola B., and Danilo M., (2012). Beekeeping and Sustainable Livelihood, 2nd Edition, Rural Infrastructure, and Agro-Industries Division Food and Agriculture Organization of the United Nations Rome, Italy.

International Livestock Research Institute, (2013). Apiculture value chain vision and strategy for Ethiopia, Ministry of Agriculture, Addis Ababa, Ethiopia.

International Trade Centre, (2015). Tanzania Honey Sector Synthesis Report and Development Road Map, Geneva, Switzerland.

Jiwa, F., (2000). Honey Care Africa's Tripartite Model: an Innovative Approach to Sustainable Beekeeping in Kenya, Standing Commission of Beekeeping for Rural Development, as Accessed from: http://www.apimondia.com/apiacta/slovenia/en/jiwa.pdf on December 26, 2015

Jun. S. Dongmyung. L. and Park. J. (2013). Determining business models in the bottom-of-the-pyramid markets. Journal of Industrial Management and Data Systems. Vol. II3, No. 7, 2013, pp I064-Io82.

Junior, J., A., Marcelo, K., Andre, L., K., and Daniel, P., L., (2004). Critical Issues about the Theory Of Constraints Thinking Process - A Theoretical and Practical Approach Paper presented at the Second World Conference on POM and I5th Annual POM Conference, Cancun, Mexico, April 30-May 3, 2004.

Kimaro D.N., Mbeyale G.E., Hella J.P., Kajembe G.C., Semalulu O. and Mogaka, H. (20I3). Modern beekeeping as an enterprise for monetary benefits, environmental rehabilitation, and biodiversity conservation: A case study of Lushoto District, Association for Strengthening Agricultural Research in Eastern and Central Africa. Feeding our region in the 2Ist century: First ASARECA General Assembly, Volume 2 pp I77-I93: Selected scientific and technical papers: ASARECA: Entebbe, Uganda.

Kinati, C., Taye, T., Kebede, D., and Tadele, T., (2012). Opportunities and challenges of honey production in Gomma district of Jimma zone, South-west Ethiopia, Journal of Agricultural Extension and Rural Development Vol. 4(4), pp. 85-9I, 5 March 2012.

Kuboja, N., M., and Jackson, N., (2015). Beekeepers Economic Empowerment Tanzania (Beet) Project: Independent Final Evaluation Report, Traidcraft Exchange East Africa, Dar es Salaam, Tanzania.

Mabin, V., (not provided). Goldratt's "Theory of Constraints" Thinking Processes: A Systems Methodology linking Soft with Hard, School of Business and Public Management, Victoria University of Wellington.

Majumder. M. (2012). A Critical Approach in Understanding Bottom of the Pyramid Propositions. Journal of Management and Public Policy. Vol. 3, No. 2, June 2012, pp I8-25. 
Masanell. R. C. and Feng. Z. (20II). Business Model Innovation and Competitive Imitation: The Case of SponsorBased Business Models. Working paper, Harvard Business School.

Matavele, R., (2014). Situation Analysis of Beekeeping in Mozambique, Total Transformation Agribusiness (PTY) Ltd, Maputo, Mozambique as retrieved from: http://www.beekeeping.com/articles/us/beekeeping_regional_situational-analysis.pdf, retrieved on December or, 2015.

Mbeiyererwa, G., A., (2014). Honey Value Chain Mapping in Njombe and Siha Districts, a report submitted to The United Nations Development Programme, Dar es Salaam.

Melhim A, Alfons W, Zach D, and Nicholas B, (2010). Beekeeping in Canada: Honey and Pollination Outlook, CANPOLIN Publication, Canada.

MINAGRI/RARDA (2006). National Beekeeping Strategic Plan Document 2007-2012, Tanzania.

MMA Limited (2007). Honey and beeswax value chain analysis in Tanzania, A Study Commissioned By Traidcraft and SME Competitiveness Facility, Dar Es Salaam.

(2012). Kigoma Honey Subsector and Value Chain Analysis Report, Study Commissioned by Beekeeping Support Project - Kigoma Region.

MNRT (200I). People and Bees, National Beekeeping Programme in Tanzania 200I-20I0. (1998). Tanzania Beekeeping Policy, Dar es Salaam, Tanzania.

Moynihan, G., P., (20I4). Application of the Theory of Constraints for Capacity Requirements Analysis: A Case Study, International Journal of Applied Science and Technology, Vol. 4 No. 2; March 2014.

Mujuni, A., Natukunda, K., and Kugonza, R., (2012). Factors affecting the adoption of beekeeping and associated technologies in Bushenyi District, Western Uganda. Livestock Research for Rural Development. Volume 24, Article \#I33. Retrieved on January 3, 2017, from http://www.lrrd.org/lrrd24/8/muju24I33.htm

Munthali, D., C., and Turner, Q., (20II). Importance of Epidemiol-surveillance: the example of Botswana, A Paper Presented at the OIE Regional Training Seminar on Diseases of Bees, I4th-I7th June 20II, Heard at Ezulwini, Swaziland.

Mwakatobe, A. and Mlingwa, C. (2006). Tanzania - The status of Tanzanian honey Trade, Domestic and International Markets, Tanzania Wildlife Research Institute, Arusha.

(2004). Role of Beekeeping in Poverty Alleviation: Market and Marketing of Bee Products in Tanzania, Tanzania Wildlife Research Institute, Arusha.

Nyatsande, S., Andrew, C., and Innocent, S., (2014). Beekeeping in Zimbabwe, a Paper presented at the APIEXPO Africa 2014 conference, Harare, Zimbabwe, 6th - IIth October 2014.

Pervez. T. Alex. M. and Anton. W. (2013). Innovation and Social Entrepreneurship at the bottom of the pyramid -A conceptual framework. SAJEMS Special Issue, I6 (2013): 54-66.

Pinda. P. M. (2014). Prime Minister, United Republic of Tanzania: an Opening Speech, The Ist Apimondia Symposium On African Bees And Beekeeping, Arusha International Conference Centre, Tanzania, November II-I3, 20I4.

Prahalad. C. K. (2012). Bottom of the Pyramid as a Source of Breakthrough Innovations. Journal of Production Innovation Management. 2012: 29(I) pp 6-I2.

Prahalad. C. K., and Hart. S. L., (2002). "The fortune at the bottom of the pyramid", Strategy and Business, No. 26, p.54.

Rahman, S., (2002). The Theory of Constraints' Thinking Process Approach to Developing Growth Strategies in Supply Chain, Working Paper ITS-WP-02-09, Sydney, Australia.

Sanchez. P. and Joan E R., (2010). Business model innovation and sources of value creation in low-income markets. European Management Review (2010) 7, I38-154. EURAM Macmillan Publishers Ltd.

Saunders, M., Lewis, P. and Thornhill, A. (2009). Research Methods for Business Students, 5 th Edition, Pearson Education Limited, Rotolito Lombarda, Italy.

Simatupang, T., M., Alan C. W., and Ramaswami, S., (2004). Applying the Theory of Constraints to Supply Chain Collaboration, Supply Chain Management International Journal, Vol. 9 No. I, 2004. 
SNV, (2009). Beekeeping/ Honey Value Chain Financing: Apiculture Baseline Study in Tanzania, Study Report Carried out by the Institute of Community and Organizational Development, Nairobi, Kenya.

The Beekeeping Act, (2002). United Republic of Tanzania.

Yin, R., K. (2014). Case study research: Design and methods, 5th Edition, Sage Publications, Los Angeles, United States. 